
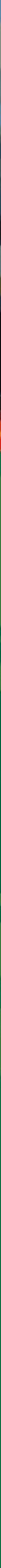


\section{Oral histories about weather hazards in northern Australia}

\section{Douglas Goudie}

This chapter draws on a collection of stories by Australian Aborigines about extreme weather impacts, mainly floods, and contrasts the embedded lessons with detailed descriptions from more recent Australian events. In the Dreamtime Australian Aboriginal stories, the recurrent theme is that everyone drowns. The ways Indigenous Australians 'read' the weather from many natural indicators may pre-empt 'technological' signs of disruptive weather.

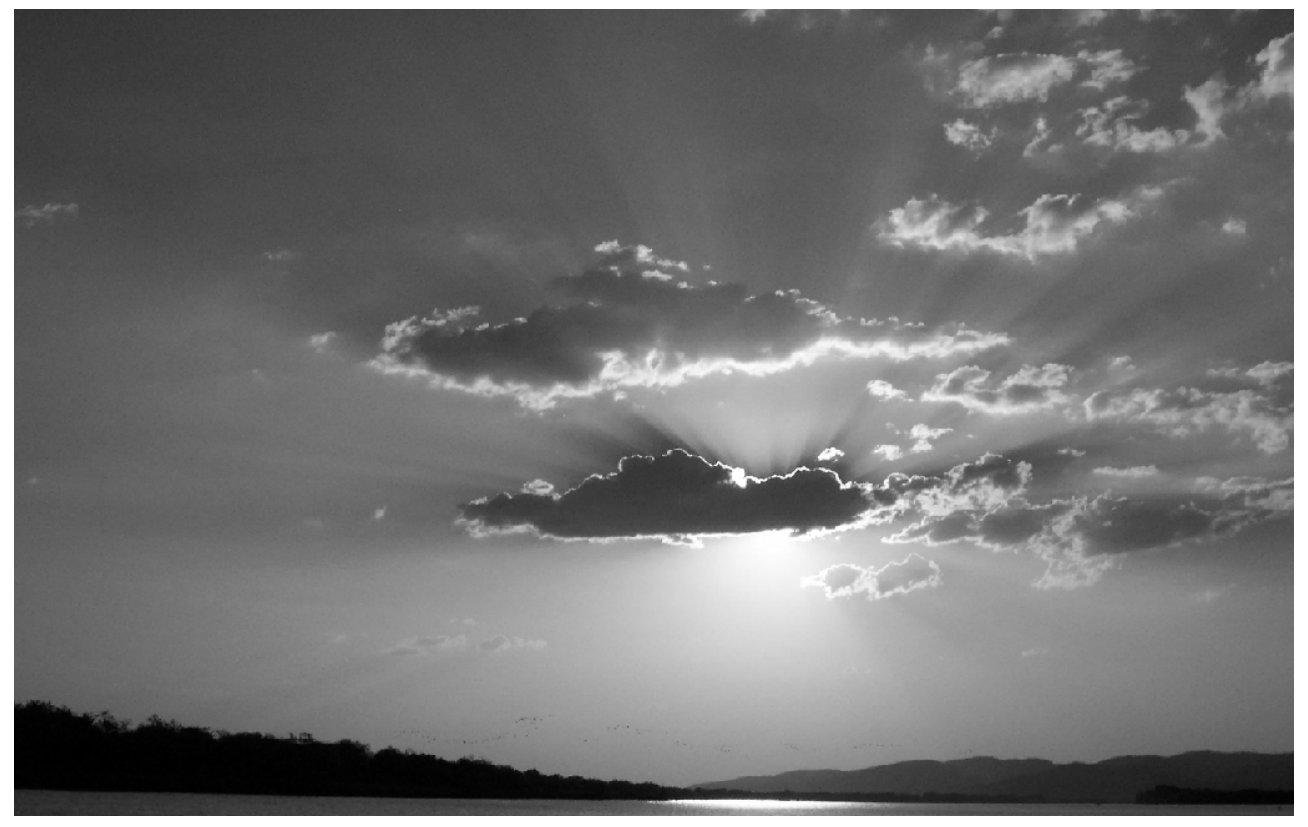

Figure 7.1 Cloud in the Kimberley - weather generally rules our lives, extremes can kill

'Safety' weather warning messages are developed to encourage aware and prepared communities to respond in a precautionary and active way to any likely threat. In more vulnerable communities, make sure residents are informed, and preferably practised in either staying safely where they are, or 
evacuating to safety early. Community safety is the umbrella under which all threatened individuals are encouraged to shelter. In Australia, infrequent extreme weather events are dealt with, and community value systems are important; safety weather warnings need to be credible. How people manage their own lives, their relationship with their local environment and their own community become central to good risk reduction. This is clear and current thinking to maximise community response and safety. People need to make and encourage choices which are robust and produce maximum safety.

\section{Old stories from across Australia}

The first two stories detail landscape and extreme events and are included to show the strong oral traditions of stories about weather in Australian Aboriginal culture. Some of the following stories long predate the rise of Egyptian culture; before Rome existed; and before other civilisations developed in other regions.

Some of the flood stories are allegories illustrating how it is perceived appropriate to respect and care for old people; others are chilling tales of what can happen if children disobey their parents, or harm animals.

\section{First story group: stories about the distant past}

\section{The Origin of Lake Eacham}

Robert Dixon (1991) recorded this story from the tablelands west of Cairns, in north Queensland.

I first recorded an account of the origin of the three crater lakes on the Atherton Tableland (Lake Eacham, Lake Barrine and The Crater) from George Watson, in the Mamu dialect of Dyirbal. The story he told was very similar to the Yidiny one given here - how two newly-initiated men broke important taboos and so angered the rainbow-serpent. This spirit then caused the earth to erupt, bringing about the formation of several deep lakes. Both texts (Dyirbal and Yidiny) provide a plausible account of volcanic eruption.

After telling the story, in 1964, George Watson remarked that when this happened the country around the lakes was 'not jungle - just open scrub.' The volcanic eruptions that formed the lakes are said by scientists to have been at least 13,000 years in the past. George was saying that at this time there was no rainforest on the Atherton Tableland. In 1968 a dated pollen diagram from the organic sediments of Lake Euramo by Peter Kershaw showed that the rainforest in that 
area is only about 7,600 years old. This suggests that the story of the volcanic eruptions may have been handed down from generation to generation for something like 13,000 years (which is not implausible, since Aborigines are known to have been in Australia for at least 40,000 years) (Dixon, 1991, pp. 41-42).

\section{How the Sea Level Rose}

Robert Dixon (1991) recorded this story from the Cairns area in north Queensland.

... a legend which must have been taken down by E.R.B Gribble between 1892 and 1909, while he was at Yarrabah, published on pages 56-7 of his The Problem of the Australian Aboriginal (Angus and Robertson, 1932) under the title 'The Great Barrier Reef':

'According to the natives on Cape Grafton, northern Queensland, the Barrier Reef was the original coastline of the country. Goonyah was the first man in that country. One day with his two wives, he went to the coast to catch fish. In some way he offended the Great Spirit Balore. It is said, that he caught and ate a certain kind of fish that was forbidden. Balore in anger caused the sea to rise in order to drown Goonyah and his women, but they fled to the mountains. The waters rose rapidly as the fugitives climbed to the heights of the Murray Prior range. This range is called by the aborigines "Wambilari" [Moses said that this must be a reference to Wumbilgay, a baldy-headed mountain]. The two women became very tired, and stopped running. Goonyah, well ahead of them, stopped on a huge boulder of granite, and called upon them to hurry. The natives took the author to this spot, and showed him the footprint of Goonyah. It is a patch of very dark stone in the granite about fifteen inches long and very wide. It is said that the mark was left by Goonyah's muddy foot. He must have been something of a giant. They succeeded in reaching the top of the highest peak in the range, and there they made a fire, and heating large stones rolled them down the mountain side, and succeeded in checking the flood. The sea, however, never returned to its original limits. (Goonganjie tribe)'.

Although Moses had never previously heard a story about Gunya the theme was familiar to him - many Yidinyji stories are concerned with rising seas and what olden times people did to try to stop them (Dixon, 1991, p. 90). 


\section{Stories from northern Australia telling of weather extremes and impacts - often most people died}

Quite a few of the stories of major events seem to have a moral of either people not sharing food (a 'sin' for nomadic, subsistence people), or of children being disobedient and tormenting animals. The latter is the case in Dumbi the owl (Utemorrah, 2000b). Here, as is often the case, every-one drowns. In Eye-of-the-sea (Utemorrah, 2000a), the vengeance of an old woman for her lost son seems to trigger a tsunami. Nearly every one was drowned and she was speared to death.

The introductory notes to Songs from Yarrabah (Moyle, n.d.) shows that the very skin or kin groups are categorised to wet and dry season groups of objects or animals. People on north east coastal Queensland were steeped in weather as part of their spiritual existence.

The accounts in The floodmakers of Langu Narnji (Trezise, 1993) record the living culture of the Mornington Island area, where legends indicate some individuals or groups were able to control storms. This was a source of intergroup power, but also retribution when a great flood, unsummoned, wreaked havoc on other groups, who then sought vengeance.

\section{Weathermen - Rain-making, Thunder, and Lightning-making}

Walter Roth (1897), an anthropologist, recorded stories about rain-making in Queensland at Boulia, Roxburgh, Lake Nash and amongst the Kalkadoon people near Mount Isa and thunder and lightning-making by the Kalkadoon people.

The Miorli men at Springvale or the Diamantina Gates execute a dance and song to bring rain. The rain-stick (koo-roo-mun-do) is made of a thin piece of white wood about $400 \mathrm{~mm}$ long. Three pieces of white quartz are glued on the end. Beard hair is added and further embellished. More than one stick may be used. Around midday the men go to a secluded water hole where preparations lead to the dance. When the rain falls the koo-roo-mun-do is removed. In the heavy floods of early 1895, Roth was later assured that all the rain and water was produced by the Miorli men. Roth notes variations of this ceremony at Roxburgh, Headingly, Lake Nash and in the LeichardtSelwyn district (Roth, 1897). 


\section{Superstition, magic, and medicine - Thunder, Lightning and Storms.}

Roth (1903) also recorded stories from far north Queensland when he was stationed in Cooktown as the first Northern Protector of Aborigines.

Thunder can make lightning, men, and women - Thunder is the most potent agency known: lightning is considered to be the fire lighted by him, ...

At Cape Bedford thunder can produce lightning by the rapid exposure of his generative organ, ... (Roth, 1903, p. 8).

These stories from north Queensland show that the Aborigines in the early 1900s often believe that men can make thunder and lightning. On the Bloomfield River storms are made by killing a particular kind of lizard. There are other ways of interfering with nature which can cause lightning and thunder. Storms can be started and stopped by men.

\section{People from the Cairns area}

Anthropologist Ursula McConnel, worked in northern Queensland in the 1930s and Alice Moyle, an enthnomusicologist, worked in the Cairns area in the 1960s.

People of the Kurakulu or Kuraminya moiety occupied the shores of Mission Bay (mira wungala), Palm Beach (giriga) and Turtle Bay. To the Wet Season division belonged water, cloud, rain, thunder, shark, "alligator" (crocodile), water snake, eel, wild duck, white timber, and other light-coloured things; to the Dry Season division belonged subjects such as rocks, clay, fire, grass, kangaroo, emu, pelican, sun, star and wind (McConnel, 1935 cited in Moyle, n.d., p. 2)

\section{The power of the Mornington Island Weathermen - The floodmakers of Langu Narnji}

This story is about the Lardil people of Mornington Island (Langu Narnji). The stories were gathered by Percy Trezise in 1964.

The tidal influences in the Gulf of Carpentaria are similar to those in the Gulf of Mexico, there being usually only one high and one low tide in each twenty-four hours. During certain phases of the moon the tide may 'double', and may also remain high or low for longer than the average period. Strong winds also have a marked effect on the tides; a 
strong persistent south-easterly may create an abnormally low tide in southern reaches, whereas a strong northerly wind, usually associated with a cyclonic disturbance, may cause the tide to back up in southern reaches and cause extensive flooding in low-lying areas.

The Lardil have many legends of great floods that occurred in the past. One story relates that during one great flood only the trees on low ridges of Forsythe Island remained above water, and the Jungarl people survived by tying their rafts to the trees. On Langu Narnji only the top of a twenty-metre-high sand ridge could be seen.

In 1948 a tidal surge which rose three metres above king tide level was said to have been caused by Shilling, a Lurrumbanda man, who, after a quarrel with the missionary, had gone to Langu Narnji to make a flood in revenge.

The Lurrumbanda say they were blamed by surrounding people for every flood which occurred, whether they had made the flood ceremony or not, and united war parties often came to attack the Lurrumbanda after disastrous floods. The Lurrumbanda exacted tribute from adjacent island and mainland clans by promising not to cause any more floods.

The floodmakers do not speak as they rejoin their families to prepare for the coming flood.

The flood may come in different ways, it may come as a giant tidal wave in clear weather, or as a series of tides, each mounting higher and higher; but it usually comes with a cyclone. The first sign from Dewallewul may be a large ring around the sun by day, and the moon at night.

Then the air becomes hot and still. The clouds become denser and darker, and the wind begins, soft and sighing at first then becoming stronger and more gusty by the hour. The rain commences and increases to a steady downpour. Gusting winds get stronger, then cease abruptly and the moaning roar of the next gust can be heard coming far off. Finally a distant roaring is heard, getting louder and louder until a powerful wind engulfs the whole island with horizontal rain and a thunderstorm roaring as it smashes all the trees. It may last for many hours and all the people can do is roll up in paperbark and huddle together on the ground until it is over. 
Due to a much lower barometric pressure, the main flood surge is contained within the central eye of the cyclone, and if its arrival coincides with a king tide it produces a flood from which nightmares and legends stem.

When the people consider they have caused enough trouble they have a meeting and ask the flood men to stop the storm. They gather up stones on the beach, make a big fire and heat them. When the stones are very hot the flood men rake them out, and using bark to protect their hands, pick up the stones one at a time and run down the beach to cast it into the tunnel of a wave as it curls over to crash on the beach. They continue until all the stones are gone and the waves know they must go back (Trezise, 1993, pp. 71-75).

There are or were many Aboriginal groups which could exercise control over the weather (e.g. Mornington Island), but the following story gives one of many spiritual or Dreamtime explanations of the weather, particularly heavy rain. With much time for contemplation, and the human desire to explain everything (the modern approach it through 'science), there are Aboriginal stories explaining just about everything.

\section{Making humans, getting children and causing flooding rains}

The Mowanjum Mission has collected many stories from the Kimberley region of Western Australia including The Spirit Water by Elkin Umbagai (1980).

Wandjina, or Ngarjaia (spirit beings) made the world and everything in it including man and woman whom he made from two of his own ribs, one large and one small, which he threw into two separate pools in which they were created. Man went back to the pools in his dreams to get children, to give to woman, to bring into the world. Wandjina protects the child spirits of the pools.

When the child is stolen from the pool, both the Snake and Wandjina are angry, and the water is stirred up to form clouds. Then there are always big rains and floods during which Wandjina and Wundgudja, the Snake, think they might find the spirit child and bring it back to the pool (Umbagai, 1980, p. 77). 


\section{Second story group: extreme impacts and older people}

\section{The Flood - Ngawarra-kurlu}

In this story by Napurrurlarlu and J akamarrarlu (1988) an old Aboriginal man has a dream of a big flood. He tells all his people of the dream and that they should not sleep in the creek, but they don't listen to him. He leaves to escape the flood. When he comes back after the flood there is no one around. During the night it rained heavily a long way up river. When the flood waters reached the camp all the people in the creek bed had to run to higher ground in the middle of the night leaving all their belongings behind. If they had listened to the old man they would not have lost all their possessions.

So the old man went back to his camp feeling so upset. He then picked up all his things and went far away where his brother was. Other people saw him coming and asked him, What's the matter? Why are you looking so sad?"

Then the old man said, "There is a big rain coming. I've seen it my dream. I told my family about the flood but they wouldn't listen at all."

Then the next day the old man went back to the creek bed to have a look and he didn't see anyone there. Then he looked around. He could see the smoke on the hill. The people told him what had happened to their food and all their things they lost in the flood. People were crying for their things they lost during the flood (Napurrurlarlu \& Jakamarrarlu 1988, p. 19).

\section{Tsunami or Cyclone? - Maambulbarda: Eye-of-the-sea}

In this story by Utemorrah (2000a), a long time ago a woman lived in the Montgomery Islands with only one son. She was persuaded to let her only son go fishing with others. The son was washed overboard in a storm and drowned. She was very distressed and sought vengeance.

"Karraai! Karraai!" she cried. "My only son, why did they let him die?" Then she thought, "So what can I do to them?"

She thought to herself for a while. "I'll stab the Eye-of-the-Sea," she said. "Wait until they're all asleep."

She stabbed the eldest of the eyes first, then she stabbed the middle eye. Only then did she stab the big one, the Eye-of-the-Sea. Away she went, paddling hard away from there. Then the sea rose boiling up after her, and it followed hard behind her (Utemorrah, 2000, pp. 99100). 
She climbed a mountain while nearly all the others were drowned by the rising sea. Some escaped and climbed the mountain too. When it was all over they stabbed her with many spears. Then they left and she is still there, on top of Mount Wundamarro.

\section{The Woman Who Destroyed the Old World}

In another story collected by the Mowanjum Mission, Jean Wungunyet (1980) provides a further example about Lake Gregory (Paruku) which is a version of the previous story, to show how the telling may be different, but the message is the same for oral history.

Near Montgomery Island, north of Broome in Western Australia, now with a large Aboriginal Reserve on the mainland to both east and west, people could live all year round as there was plenty of food. An old woman and her people lived there hunting and fishing.

Her husband would share his turtles or fish with the group but not with his wife so she vowed to:

destroy these people, because they don't give me any of their meat.

So she set out in her canoe to live alone on the coast. Out on the reef were two blow-holes, one big and one small. She picked up her wooden spear and stirred and poked the waters with it. Immediately the waters started to bubble and rise. She walked across the reef and climbed the highest hill she could see. The water rose and rose and flooded over the land.

Some of the men saw the woman on the hill and decided that she was causing all this trouble. They chased her with their spears and killed her. But they were too late - everyone was drowned.

And that is the story of the great flood. Even today our people are afraid to go near that place where the waters boil over (Wungunyet, 1980, pp. 90-91).

\section{Flood - The Flood and the Bird-men}

This story from the Northern Territory was related by Kianoo Tjeemairee (1968) of the Murinbata tribe. The story was translated by Roland Robinson and it tells how heavy and continuous rain fell day and night until the land was flooded by the rain waters and the rising levels of the sea. 
In the time called Kardoorair which means At first all things were blackfellows, a big rain began to fall. It fell all night, all day, all night, all day. The water began to cover all the Murinbata country called Darimun. The rain did not stop. The water filled up the creek and the sea came up and covered all the country, the hills, the trees, everything. There was only water (Tjeemairee, 1968, p. 87).

\section{The flood and its result}

This story by David Unaipon (2001) is a flood story of the Berrwerina people of the Darling River area.

A long time ago there were so many families of animals they found it difficult to live together and so they had a great conference to try and address the situation. One particular tribe related to the reptiles had rainmaking abilities and their totems were:

the elements Lightning, Thunder, Rain, Hail, and Wind. They were becoming important. They resolved that they would not consult anyone, but act as they pleased. This selfish family was the Frilled Lizard. They sent representatives to various parts of the country with the instruction: 'On days and evenings of the week preceding the new moon, let every Thunk cum bulli (Lizard) begin the singing of the Storm Song.'

And when the time arrived, they took their flint knives and cut the body, causing the blood, and then they smeared the body with fat and red ochre and daubed the face with pipe clay, and then began chanting their prayer song, pleading that the Great Spirit of the Lightning, Thunder, Rain, Hail, and Wind should grant this their humble request: 'Come oh Thildarrin (Lightning), come oh Rroararund (Thunder), Pa noondi and Miyundi, come with all thy force and destroy the Platypus family, they have become too numerous and they are more easily overtaken in the flood than any other tribe.'

And they sang and sang their song of the Storm until the last few days and evenings before the appearing of the new moon. Then great dark clouds began to mantle the clear sky, and out of the black cloud the lightning flashed and rent the darkened sky and earth, and struck terror into the hearts of the Animals, Birds, and Reptiles. And the thunder roared its reply to the angry lightning flash, and the winds came hurrying, all in response to the thunder's voice, tearing the limbs from the huge towering gum trees, uprooting smaller trees and shrubs, 
strewing them along its path, driving the rain and hail into every hiding place of Animal, Bird, and Reptile.

When the Bird tribe saw what was coming, they took to their wings, and mounted upon the wind, up and up, until they were far beyond cloud and storm, into lands beyond the sea. The Animals struggled into the blinding storm, seeking shelter up and up, dodging behind the trees and rock boulders of the mountain-side, until they reached the summit, seeking a place of safety. Thus ended the conference with no satisfaction but desolation and death.

It rained and rained. The valleys and low-lying countries were deluged, all life living therein was nearly all destroyed in the great flood (Unaipon, 2001, pp. 28-29).

\section{Kalpartu the Dreamtime Snake}

This flood story from Gracie Greene, J oe Tramacchi and Lucille Gill (1992) is from Billiluna country south of Halls Creek.

The Willy Wagtail man came for a visit but the people tried to keep him out of the dances. They teased him and made him feel unwelcome.

So Willy Wagtail man went for help to his cousin brothers, who were Dreamtime snakes.

The snakes surrounded the dancers. They made a big flood, which killed all of the people except for one, who changed into a white corella. Now you can see these white corellas. They stay near the rockhole. They are the people who lived there in the Dreamtime (Greene, et al., 1992, pp. 27-28).

\section{Flooding of Sturt Creek and Lake Gregory}

Readers are invited to compare this following story from George Nunkiarry (1996), a flood story from the time before the arrival of non-Aboriginal people, with a version by Rex J ohns as related to the author in 2003 which is presented following the Nunkiarry story.

In the Dreamtime there came a huge flood from the east. It brought my ancestors from the east to Lake Gregory. It came downstream 
straight for where Inverway Station now stands. The flood came from Gulbulundu and headed down towards Birrindudu. It filled Sturt Creek to overflowing. J ust the tips of the river gums along the bank stuck out of the water. White people, if they had seen it, would have said it was just like a tide coming in. From bank to bank it swept down to where Gordon Downs is today, to the south of the river. As it ran it met up with other floodwater from the north and west. That was where the crocodile and the goanna fought over their teeth. The crocodile stole the goanna's sharp teeth.

The flood kept sweeping downstream and met smaller floods at Bindi Bindi or Sturt Creek Station. It filled up all the big waterholes along the river as it passed by Sturt Creek Station. As it went, the flood swept up birds of all kinds, ducks, guluyu - bush fowl, white people call them. It swept them all downstream towards Lake Gregory in the south, where two pelicans saw the flood and all these birds approaching. One of the pelicans said, 'I'll go north and meet all these birds and bring them into the lake.' We say dabarunga but white people say pelican.

The two pelicans came up from the south and met the duck, and the bush fowl, and the brolga, and all the other birds caught in the flood. And that is how tribal laws from the south and the north met at Lake Gregory. In the Dreamtime the two pelicans brought all the birds together at Lake Gregory.

Billiluna used to be beside the lake; Billiluna old station, which we call Warngu. They moved Billiluna north to the higher ridges, and they built new houses. It used to be much closer to the lake. From Warngu, in the Dreamtime, two white dogs started to chase an emu. They chased it for along way to the west. White people might say they chased it for twenty or a hundred miles. We just say that they chased it for a long way west.

After some time, the emu started to swing around and run back the way it had come. Back towards the lake which is called Barugu. Finally, at the lakeside, the dogs caught the emu and cooked it and ate it. You have to remember in all these stories that the animals in those times were like people. After that the lake began to fill up from the south bank to the north. Barugu is huge. It might stretch as far as from Old Town to Palm Springs. To go around it is like going from Halls Creek to Fitzroy or perhaps to Wyndham. 
Well, the whole lake started to fill up. White people would say it is like an ocean. We went round it once and it took us two nights camping to get around. My grandfather, grandmother and my father lived there and that is where they are buried (Nunkiarry, 1996, pp. 10-11).

\section{Mulan Dreamtime story - The two dingoes}

This story is from Rex J ohns, Mulan elder and founder, as related to the author in 2003.

There were two emu up north from around Inverway Station, from Nungaroo Creek who were chased by two dingo. A big distance away at Nungaroo.

People were walking south. The emus were in front. The people were singing and dancing, and they were in between the dingoes and the emus. There were floodwaters behind the dingoes.

When people were camping the flood would stop. There was one old man, he had a string line and he would cut the water while they camped. He would hold the waters back while they camped. While they would sing and dance. Where they camped the water was held up. That is where the billabongs in Sturt Creek are now. Like at Bindalaorro. The black and white water bird, the one with the long legs, the little bird was with the people. Birds and other animals joined the people as they moved south, singing and dancing.

They were coming down, straight down to the lake on the Sturt River side. But the dingo chased the emu round the other side. Around to number 51 well (water bore) around to Gillang-gillam.

The dingo chased the emu back and forth on the main lake. One dingo was chasing one emu and the other dingo was chasing the second emu. Back and forth. Each dingo grabbed an emu when they passed but they each grabbed the wrong emu. They grabbed 'em and killed 'em and ate 'em.

The people on the other edge of the lake, in the main channel, camped again. In that main camp they sung and danced, that was where we call Lera Yard. 


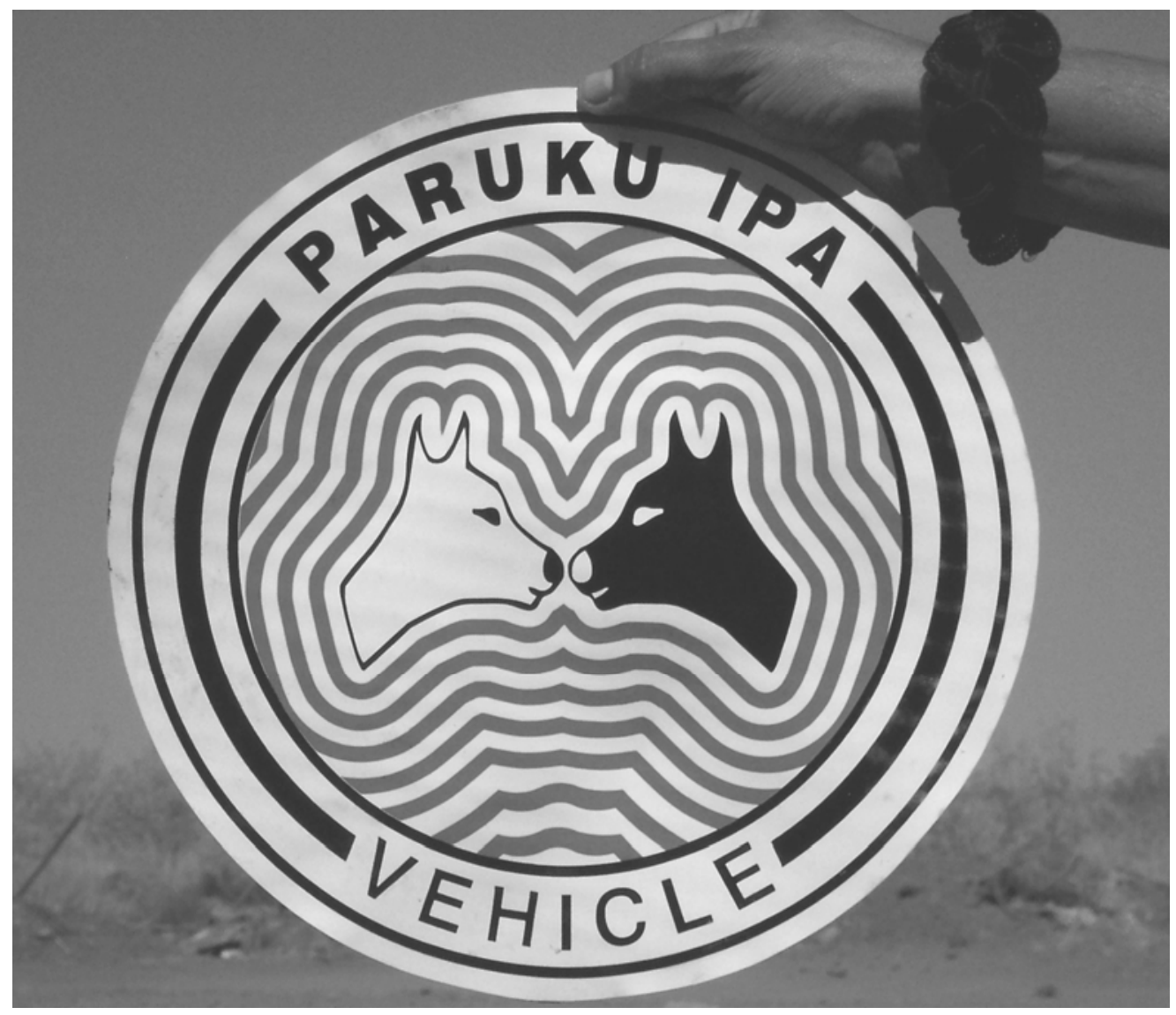

\section{Figure 7.2 Two dingoes - the story of the great flood of the Sturt Creek}

When the two dingoes were full they walked up the other channel to Mulan. There was a soak there and they dug in. They're still there.

Then the water came in from both sides and all the people got drowned.

One old man walked off and sang them (he put a deadly curse on them all). They all drowned because they hadn't shared some food with him. But when he walked off, another old man spat on him, cursed him, so that first old man who walked off died too (personal communication, Rex J ohns, October 2003).

The Sturt Creek and Paruku (Lake Gregory) are central links for the desert communities in the East Kimberley. It is now common knowledge around Mulan that if the early floodwaters are a milky colour passing through the Balgo Hills area, it means a major flooding rain north, about five days 
earlier, and the creek levels would probably stay high for months. If the water was red, it means local rains from the smaller, near catchment, so the creek level would probably go down in a few days.

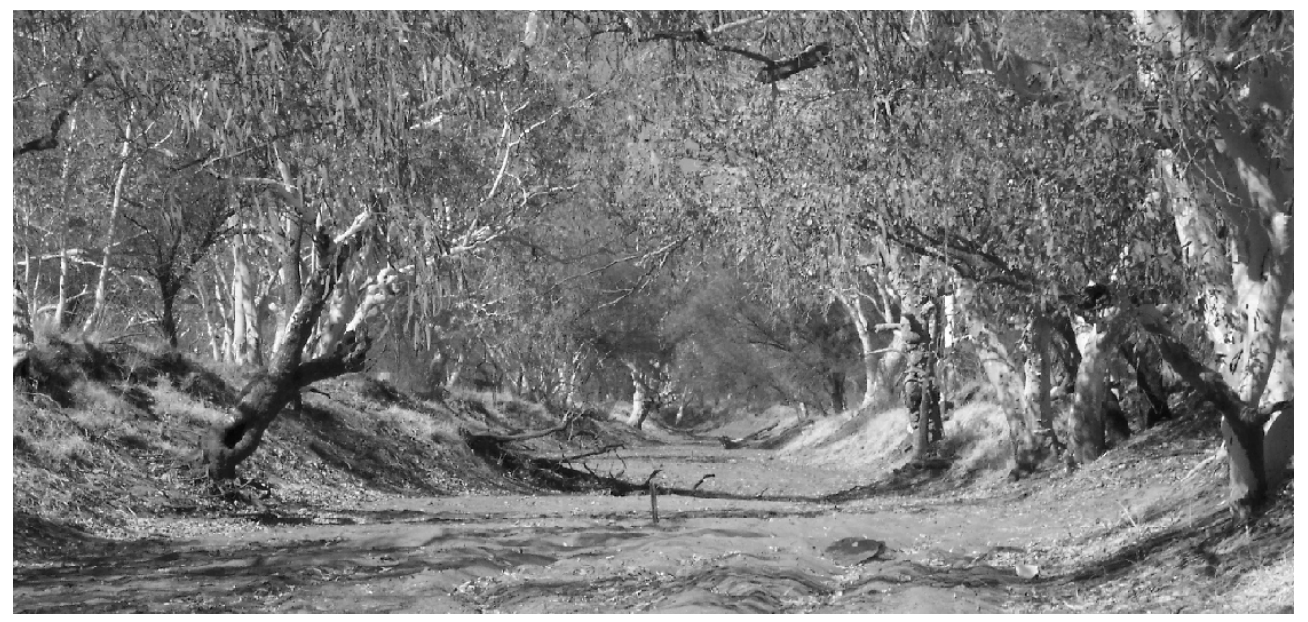

Figure 7.3 Sturt Creek, subject of a Dreamtime story of flood and loss, which includes moral teaching.

\section{Floods and discipline lessons for children}

\section{How the people were all drowned}

In another story collected by the Mowanjum Mission, Daisy Utemorrah (1980) provides a flood story How the People Were All Drowned. In Aboriginal Dreaming a tribe called Dillangari from north west Australia had huge dogs as big as calves. Wandjina didn't want the dogs to talk and if they did he would drown everyone.

So parents were very careful to tell their children never to tease a dog.

The tribe went to hunt at a place with plenty of food, the men telling the women to make sure the children didn't tease the dogs, "and the women gathered the children together and warned them, 'First of all, you must not hit any special bird which belongs to Wandjina, such as Tumbi, the Owl. If you do, the Wandjina will send rain and storms and we all will be drowned. And the second thing is that you must not tease the dogs. Don't try to make them talk like us because Wandjina has told the dogs that they are only allowed to bark.'

The children asked why they couldn't play with the dogs, and the women answered, 'If you do, and a dog answers you, we will all be 
swallowed up by water. No one will survive. The Wandjina will cause the water to rise and drown us all.' So the children agreed to leave the dogs alone.

Some of the women went off to look for berries and wild honey and yams. The remaining women were told to keep an eye on the children, but instead of doing this, they went down to the river to gather waterlily roots.

A group of children started to play with the dogs, calling and yelling to them. The women were so busy with the waterlily roots that they didn't hear the children, who continued to tease the dogs. Suddenly one of the dogs answered back, speaking like a human.

As soon as that happened, Wandjina caused the whole tribe to disappear under the ground and under the water. Only the Wandjina themselves were left (Utemorrah, 1980, pp. 46-47).

\section{Dumbi: The owl}

In another story by Utemorrah (2000b) young children were told not to torment the owl. One of the boys decided to kill the owl. Others tried to stop him but he climbed into the tree, grabbed the owl, pulled out all his feathers and threw him down. They stabbed the owl and tormented him in many ways. The Wandjina (spirit being) wanted to know from the owl what happened. When the Wandjina found out he decided to punish the children by getting rain. He got the dragon lizard to go out into the plain and wave his arms around to bring all the clouds. The dragon lizard did that. The rain and lightning came. That scared the children. Their parents came back and asked why was all this rain falling and discovered what had happened. The children said they were only playing with the owl.

“Well, we told you and told you, when you see the owl you mustn't hurt it. But you just wouldn't believe us.

The rain kept falling. The rain fell and lightning flashed all around them. They swam about in the flood waters, trying desperately to climb up into the highest hills. But the flood rose up higher and they all perished.

But there were two children standing up on a hill, a boy and a girl. And a kangaroo came hopping towards them. "Let's climb onto this kangaroo," they said to each other. 
...the Wanddjina destroyed all the other people. They all drowned and the land was left empty (Utemorrah, 2000b, pp. 9-11).

\section{A moral story with dire weather consequences}

In Daisy Utemorrah's story above the torment of an owl resulted in a great flood in the Kimberley. The Wandjina got the dragon lizard to go out into the plain and wave his arms around to bring all the clouds. The dragon lizard did that and the rain and lightning came and the children were frightened.

During a disaster risk management study conducted in Eidsvold, inland from Gympie, southern Queensland, the author learned from Neville, of the local Wakka Wakka group, that he spent time with traditional men in the 1950s. He was shown a local lizard (moos moos in the Wakka Wakka language) slowly waving one 'arm', then the other in front of its face, while standing on a high piece of a fallen branch. These lizards are smooth skinned, not very common, and about $200 \mathrm{~mm}$ long. The old men said that event meant there would be rains soon after. The younger blokes laughed and thought that was not going to happen. According to Neville, "storms came from all over the place that night. It rained a lot" (personal communication, Neville, 2003).

From an ancient story of a prior major flood in the Kimberley to living oral traditional knowledge of reptile behaviour preceding flooding rains in southern Queensland, there would appear to be an early, observable warning or forecast of rain.

\section{Lightning}

J ean Ellis (1991) collected this story The Lightning Man about the legend of Wala-Unayua who lived deep in a waterhole in the Liverpool River in Arnhem Land. Local people knew he was easily angered and would strike people down with lightning.

He was at his most dangerous, however, during the wet heat of the monsoon season. As soon as the monsoon rain began to fall, WalaUnayua would fly into an uncontrollable rage. In that rage he would travel across the sky, hiding in thick clouds, and his angry voice would thunder, crashing and echoing across the land.

Flashing the lightning of his long arms and legs he would savagely attack the earth, throwing down the trees and leaving a stricken landscape in his path. As soon as the monsoon season came to an end he would gradually become calmer, eventually returning quietly to his own waterhole. There he would stay, always on the watch, ready to 
strike out again if anyone or anything dared disturb him (Ellis, 1991, p. 106).

This section shows that old stories, Dreamtime stories for Australian Indigenous people, can help make real the rare and unusual threats of flood, fire or destructive winds which may impact upon people's lives in the future. It should be possible for these old ways of reading the weather to be communicated into the technological and hard data' systems employed by the Australian Bureau of Meteorology to help predict flooding rains.

\section{Readable weather warnings, direct from nature}

The following compilation of traditional weather predictors results from a team of researchers from James Cook University's Centre for Disaster Studies visiting many northern Australian remote Indigenous communities in late 2003. With the core business of finding out from communities about how to maximise the safety of communities ahead of disruptive weather, researchers also asked community members: 'What natural indicators tell people that there is going to be, or likely to be, a bad or dangerous weather event (including bushfire, flood, severe storm, cyclone, surge, cold snap, drought etc.)?' They were also asked: 'What are the natural indicators for the onset of the wet, and the dry season?' and 'What kind of traditional ways do people have of recognising or predicting a change in the weather and an increase in a hazard?' Some 'weather reading' techniques are explained below.

\section{Yarrabah}

From Yarrabah, near Cairns, in coastal far north Queensland, people can tell if storms are coming because ants are more common indoors, and cockroach behaviour is erratic before a big wet. Certain plants and flowers are used to indicate seasonal changes. The behaviour of the storm bird, a type of tern, is erratic. This bird flies low or circles in the sky and flies off in the direction of the coming cyclone just days/hours prior to the event. Also, increased numbers of crocodile tracks and drag marks heading up the mudflats/ beach indicates that it is going to be rough weather at sea for about the next week, possibly due to storm or cyclone. A dark, shadowy ring around the moon means that bad weather is coming. Unusually high tides means a storm is coming - conversely 'blue' sea water close to shore is said to indicate good weather for the next couple of days.

When the bush creatures are quiet, it means the birds have left for the mainland, and there will probably be a big storm or cyclone. This may 
happen before the formation of a storm has become clear by way of electronic means.

\section{Palm Island}

From Palm Island, near Townsville, major storm indicators include large amounts of cloud and fine mist. A red sunset probably means major rain and crabs moving inland may indicate cyclones. Similar to Yarrabah, major storms are signalled when birds gather in flocks and fly around quickly before leaving the area. It is known that when you are in the path of a big storm it all goes quiet - all the birds have left. That kind of quiet will tell you where the worst of a cyclone is going to hit.

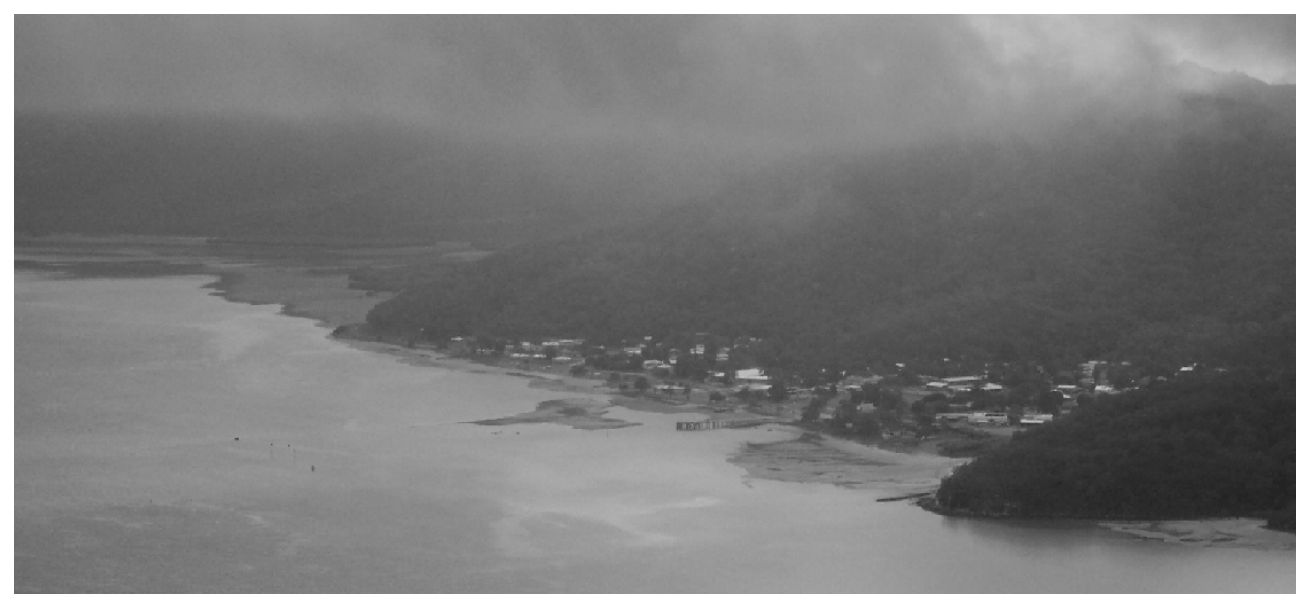

Figure 7.4 Main settlement, Palm Island

People of different cultures know that cockroaches and ants become very active before bad weather. Sudden changes in wind patterns may indicate a storm is on the way and cloud types may indicate approaching storms.

All the bush animals breed up ahead of a good wet season, but they would not breed much if there was not going to be much of a wet. With the traditional fruits - when all the trees were in fruit, one tree may start to fruit again. People would know that something unusual was going to happen, that different weather was approaching.

\section{Old Mapoon}

In Old Mapoon, on the Cape York Peninsula in northern Queensland, traditional ways of reading the weather are much the same as all communities in northern Australia. A period of continuous very hot and still 
conditions precedes monsoonal rains or a cyclone. Indigenous elders state there are certain natural indicators for different types of weather events, the most important predicting cyclones.

Many local people indicate the manahawk (Aboriginal name for a large black ocean going frigate bird) when seen in large numbers in the coastal areas indicates that strong winds, possibly cyclonic, are expected within two to three days. Bad weather can mean severe storms or a cyclone. In normal weather conditions, these birds can be seen circling in a group, high in the air along coastal areas. When conditions are extremely rough, in the case of an approaching storm or cyclone, they move inland to seek shelter, flying low to avoid wind gusts.

Crocodiles building their nests higher than usual above the high tide mark and long stalks on the mango fruit indicate that a big wet with greater than average seasonal rainfall is expected. The wet season is heralded by a gradual build-up of clouds over weeks, high tides, and very hot conditions. When the dry winds start to blow from the south east, causing the grass to lose all moisture, turn brown and die off, winter is beginning.

\section{Kimberley region}

At the Kimberley settlement of Ringer Soak, ants are observed about 6 weeks before the wet to start building tubes up from the ground about 2 inches (50 $\mathrm{mm}$ ) high. The ants close off the top of the tubes just before the rain starts a day or two before. J ust before the wet the bees gather pollen then seal off the combs with wax, just leaving a tiny breathing hole. Budgerigars and goannas come out with the lightning and thunder near the start of the wet, while the budgerigars breed at the end of the wet. First there are rains, then there are the flying ants. If there are more flying ants there will be more rain. It is known that most of the weather comes from the north east. Bush trees start to flower after a cold snap, and the Sturt Desert Pea stops flowering at the end of the wet. 


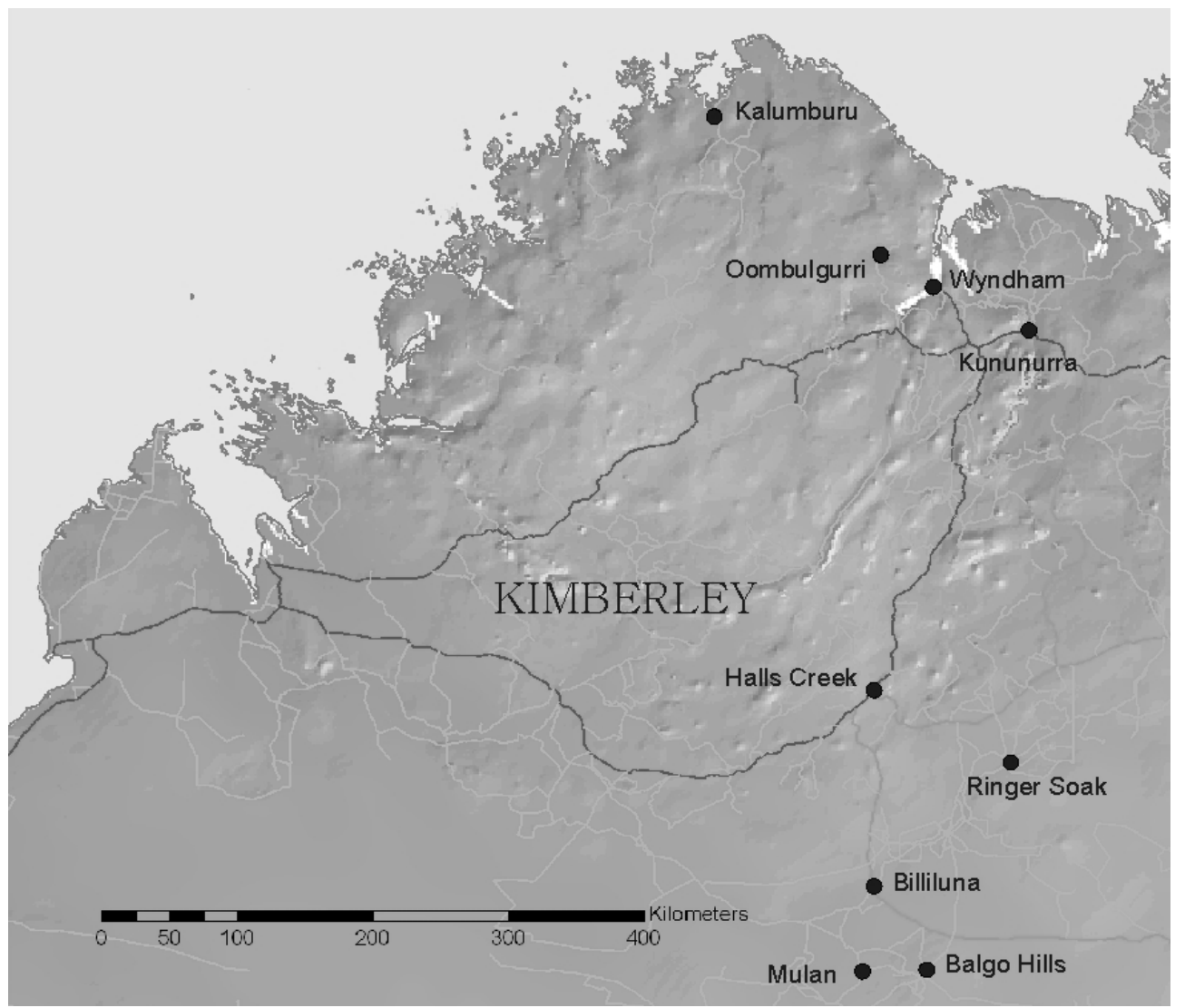

Figure 7.5 The Kimberley region of north west Australia [map by Adella Edwards]

In Mulan in the Kimberley, the days are hotter before the rain, in October or November. The cicadas are heard and then there are big rain clouds and goannas become active. There is some rain, a dust storm, rain, then lightning strikes then the wet. In Balgo Hills, the ants store food night and day indicating there will be heavy rain in about three days. J aum is the local name for the rains that come after Christmas. The weather seems to follow a four or five year cycle. Clouds go round in circles just before the rains come. In Billiluna, the start of the wet is indicated by ant activity, big cloud banks and the general humidity and temperature build-up. 


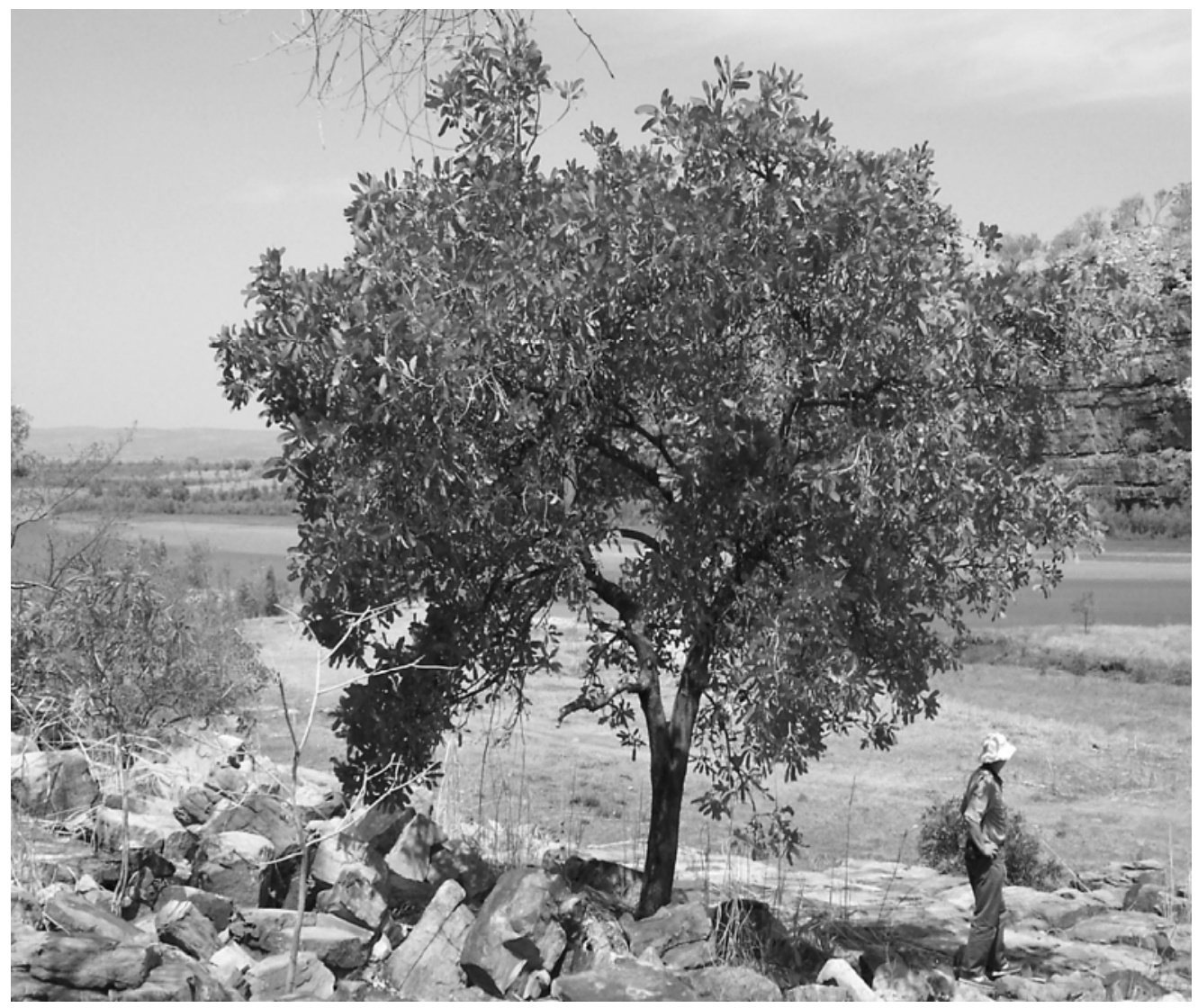

Figure 7.6 Forrest River landscape at Oombulgurri in the Kimberley

In Halls Creek in the Kimberley the onset of the wet season is heralded when the leaves have fallen off the trees and they've begun to grow back. The clouds building up, days getting hotter, and hot, dry wind blows. The boab trees will flower and when these flowers fall it means the rain will be coming soon. Echidna will walk, looking for ants. Green frogs start making noise, before it starts raining. Sugar bag or wild bee hives are full of honey, and rain can be predicted by the tilt of the quarter moon: if the quarter is on its back, not much rain; if the quarter is standing tall, it should be a good wet. When there are rings around the moon at night, the more rings the bigger the wet.

The onset of the dry season is signalled when cockatoos and blue mountains parrots lay eggs. Nights get colder and flies are a major pest until the weather starts to get cold. The sugar bag flies come out and start laying eggs, and sugar leaf grows on the leaves of trees. If there has just been a big wet, there is more chance of having a colder winter. 
Traditional ways of recognising or predicting weather change can include: looking at the sky for clouds or lightning in the distance; following the direction of the wind, especially if rain or lightning are near; and watching insects, birds and animals, the known indicators of imminent rain and wind. The abundance of bush fruits and animals which should be in season is also a way of recognising the change in weather.

In Oombulgurri (the former Forrest River Mission) in the Kimberley people say they can smell the onset of the wet. There are flowers before the wet, like the kapok and the gelay. Boab trees start shooting leaves. You get the knock-down' rain at the end of the wet, the rain that knocks down all the dead grass stems right before the dry starts. The wet is known to have finished when the fast moving cloud is observed.

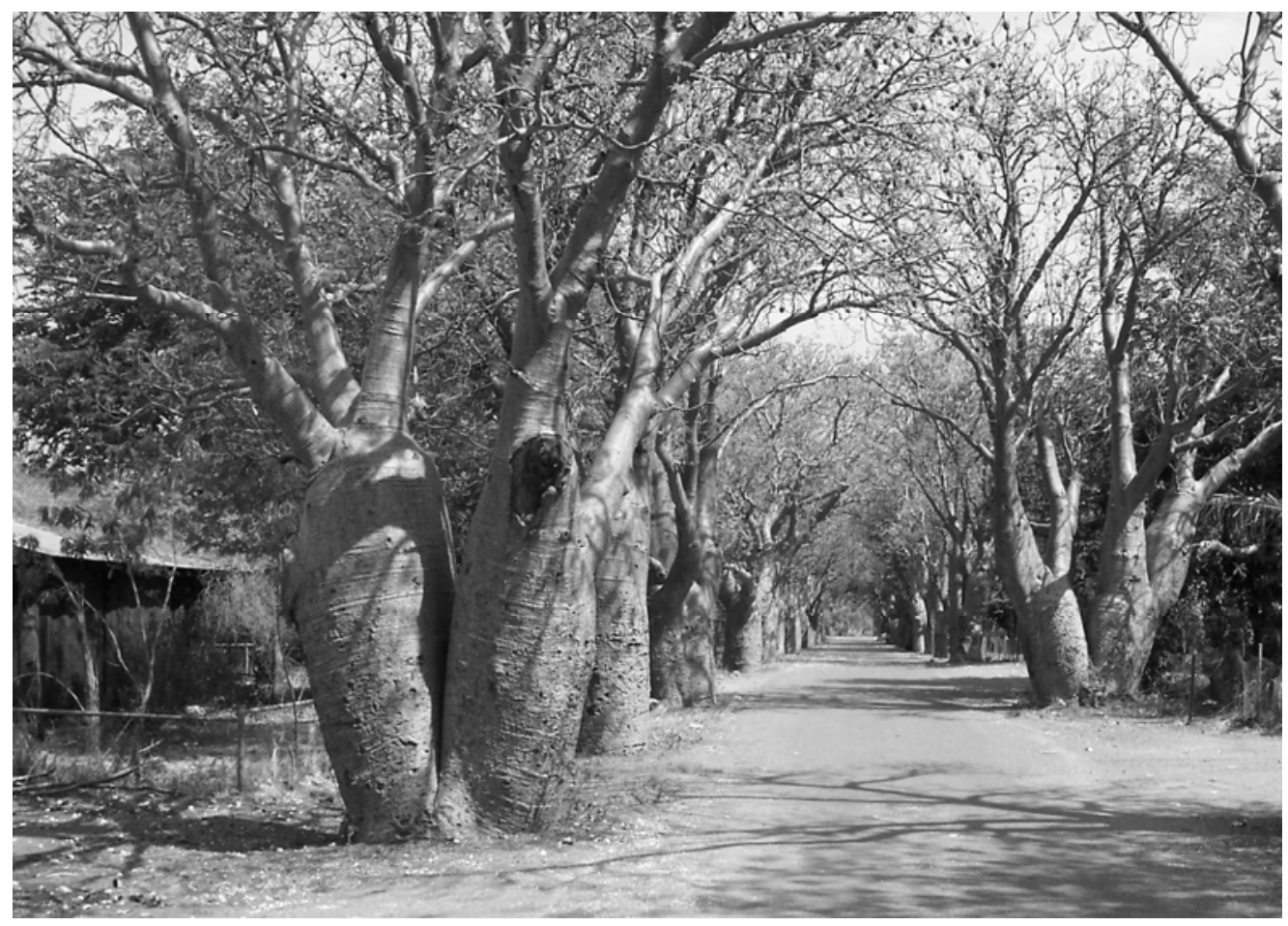

Figure 7.7 Boab trees in Oombulgurri in the Kimberley

\section{Conclusions}

This chapter has shown that there are knowable threats from extreme weather, recorded in the oral traditions of Indigenous peoples, and in more recent western accounts. It is also clear that some of the learned indicators from widely separated areas are good predictors of disruptive weather, from 
lizards waving their front legs about, to sea birds wheeling in unusual groups. Simple observations such as: 'the bush goes quiet because all the birds have left' could save lives ahead of a cyclone impact, if the traditional knowledge had remained widespread, respected and used. It is still possible for much Indigenous weather knowledge in Australia to be used in this manner.

Making the threat real to endangered listeners is the core to effective 'safety' weather warnings. The old stories provided in this chapter, call them Dreamtime' or 'folklore', tell of extreme weather events, while the living cultural knowledge gained and passed on over thousands of years tells, how to 'read the weather' locally. A long-term outcome of technological weather predictors testing could be to respect and learn from Indigenous weatherreading methods. Indigenous weather stories and readings could be incorporated into education about weather patterns. To maximise safety, credible warnings and action statements from reliable sources need to be received and responded to appropriately. This is central to the purpose of safety weather warnings: use of material in this chapter may help savelives. 